\title{
Mode of Action of ACTH-An Adrenergic Receptor Mechanism in Adrenal Steroidogenic Response to AGTH
}

\author{
S. MATSUKURA \\ Division of Medicine, Kyoto Hospital of Japan Monopoly Corporation, Kyoto, Japan
}

Cyclic 3', 5'-AMP has now been established as an intracellular second messenger mediating many of the actions of a variety of different hormones including ACTH. The level of this nucleotide depends upon the relative activities of at least two enzymes, viz., adenyl cyclase, which is at first activated by each hormone and catalyzes the conversion of ATP to cyclic AMP, and phosphodiesterase, which catalyzes the breakdown of cyclic AMP to 5'-AMP. It has been recently reported that the metabolic effects of catecholamines are differentially affected by alpha and beta adrenergic agents. Stimulation of the alpha adrenergic receptor inhibits, and stimulation of the beta adrenergic receptor enhances the effects of catecholamines on cyclic AMP accumulation probably via their effects on adenyl cyclase. This is also the case with vasopressin and MSH. Few deta have been reported about the role of an adrenergic receptor mechanism in adrenal steroidogenic response to ACTH.

In the present study both alpha adrenergic blocker, thymoxamine ( 5 to $50 \mu \mathrm{g} / \mathrm{ml}$ ). and beta adrenergic stimulator, isoproterenol $(1 \mu \mathrm{g} / \mathrm{ml})$, were found to potentiate the rat adrenal steroidogenic response to ACTH in vitro, while both alpha adrenergic stimulator, methoxamine (1 to $20 \mu \mathrm{g} / \mathrm{ml}$ ), and beta adrenergic blocker, alprenolol (10 to $25 \mu \mathrm{g} / \mathrm{ml}$ ), to inhibit the response to ACTH. These results indicate that the general hypothesis (increase of hormone response by stimulation of the beta adrenergic receptor and decrease by stimulation of the alpha adrenergic receptor) may be valid in adrenal steroidogenic response to ACTH in vitro. Alpha adrenergic stimulator, phenylephrine ( 1 to 20 $\mu \mathrm{g} / \mathrm{ml})$, and alpha adrenergic blocker, phentolamine $(5 \mu \mathrm{g} / \mathrm{ml})$, had no effect on the steroidogenesis induced by ACTH at the amounts used. Beta adrenergic blocker, propranolol $(5 \mu \mathrm{g} / \mathrm{ml})$, was shown to interefere with fluorescence of corticosterone by sulfuric acid-ethanol, resulting in the apparent potentiation of adrenal steroidogenesisby ACTH in vitro. Adenyl cyclase in rat adrenal homogenate was activated in the presence of isoproterenol and thymoxamine, and inhibited in the presence of propranolol, lending further support to the involvement of an adrenergic receptor mechanism in the adrenal. These adrenergic agents had no effect on phosphodiesterase activity. Prostaglandin EI (0.5 to $20 \mu \mathrm{g} / \mathrm{ml})$ was without effect on the steroidogenic response to ACTH. Omitting calcium from the medium and adding EGTA $(1 \mathrm{mM})$ completely abolished the effect of ACTH on steroidogenesis and partially inhibited the dibutyryl cyclic-AMP-induced steroidogenic response. Theophylline $(1 \mathrm{mM})$ decreased rather than increased the ste- 
roidogenic action of ACTH and was without effect on the response to submaximal dose of dibutyryl cyclic AMP. On the contrary, imidazole $(1 \mathrm{mM})$ potentiated the action of ACTH on steroidogenesis. These contradictory effects on adrenal steroidogenesis by ACTH may be explained by the possible action of these two agents on protein sythesis in rat adrenal tissue, a process which is essential for the steroidogenesis by ACTH. The fact that addition of cycloheximide $(0.4 \mathrm{mg} / \mathrm{ml})$ to medium inhibited completely the AGTHinduced steroidogenesis in vitro, also confirms the importance of new protein synthesis.

(See pp. 618 624) 


\title{
シンポジゥム I ホルモンの作用機序
}

\section{ACTH の作用機序一特に Adrenergic Agents の意義}

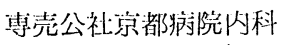 \\ 松倉议
}

1 緒訔

Haynes ら’により cyclic 3'，5'-AMP (G-AMP) が ACTH による副腎皮質ステロイド産生の細胞队 mediator であるととが提唱されて以来，G-AMP の second messenger としての役割が注目されている゙23. われわれも白ネブミにおいて in vivo で C-AMP およびより強力な誘導体 dibutyryl cyclic 3'，5'-AMP (DBC-AMP) の投与により ACTH 同様ステロイド産生が増加するととを認めている ${ }^{4)}$. Grahame-Smith $ら^{5)}$ はさらに白ネズミ副腎に ACTH を添加すると corticosterone 産生增加に先立つて C-AMP の増加が起て り，しかもその增加は添加した ACTH 用量に相関するてとを報告している．従つて G-AMP が ACTH 作用の細胞内 mediator であることはほぼ確象であるが，次にての nucleotide が如何なる機序で mitocondria 内での cholesterol の酕素的水酸化反応による pregnenolone への転換に関与しているかは明らか でない. Haynes らやの AGTH がまず G-AMP を産生し次いでしれにより phosphorylase が活性化され glycogen 分解に始まる解糖過程によりステロイド痤生に必岁な TPNH が産生されるという仅説も必ずし も凑験的に証明されていない゙). 今回 ACTH の C-AMP 産生を介するステロイド産生経路が catecholamines の adrenergic receptor ${ }^{7}$ に類似しているてとから各種 adrenergic agent および adenyl cyclase 系に関与する若干の楽剤のステロイド産生への影響を検討した。

\section{2 実 験 方 法}

体重150-200 g の雄白ネズミを断頭後副婜を摘出し脂肪を取除き半切し， $2 \mathrm{ml}$ Krebs-Ringer bicarbonate buffer ( $2 \%$ 牛血清アルブミンと0.01Mブドウ糖を含む) 中で $95 \% \mathrm{O}_{2}, 5 \% \mathrm{CO}_{2}$ のもとに $37 \mathrm{C} て ゙ 30$ 分 間振とうしながら preincubate した。次いで各種楽剤を加えた新鮘な medium 中で 1 時間同㥞に incubate し， medium 中に放出された corticosterone を硫酸螢光法帛により測定した。

adenyl cyclase 活性の测定は Taunton ら 9 の方法により ${ }^{14} \mathrm{G}-\mathrm{ATP}$ を $2 \mathrm{mg}$ 相当の白ネズミ副腎 homogenate と10分間 $37 \mathrm{C}$ で incubate し，産生された ${ }^{14} \mathrm{G}-\mathrm{C}-\mathrm{AMP}$ を Dowex 50 column を使用せぜに $\mathrm{ZnSO}_{4}, \mathrm{Ba}(\mathrm{OH})_{2}$ で 3 回遠沈分離後 ${ }^{10)}$, 上清の放射能を Bray 氏液に加え liquid scintillation counter によ り测定した. phosphodiesterase 活性はChase ら ${ }^{11)} の$ 方法により ${ }^{3} \mathrm{H}-\mathrm{C}-\mathrm{AMP}$ を $2 \mathrm{mg}$ 相当の副緊 homogemate と $37 \mathrm{C}$ で 3 分間 incubate し同様な方法で一回遠沈分離後上清の放射能を counter で测定し，水解された ${ }^{3} \mathrm{H}-\mathrm{C}-\mathrm{AMP}$ の量であらわした.

\section{3 実 験 成 績}

1) DBC-AMP の in vitro でのステロイド産生への影響 各用量の DBC-AMP を medium に添加す ると dose-dependent なステロイド産生がみられ, in vitro でも ACTH 同様な効果が認められた（Fig. 1).

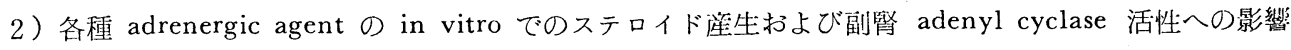
第46巻 第 6 号 
Fig. 1. Effect of graded doses of dibutyryl cyclic AMP on adrenal steroidogesis in vitro. Each bar represents the mean \pm SEM.

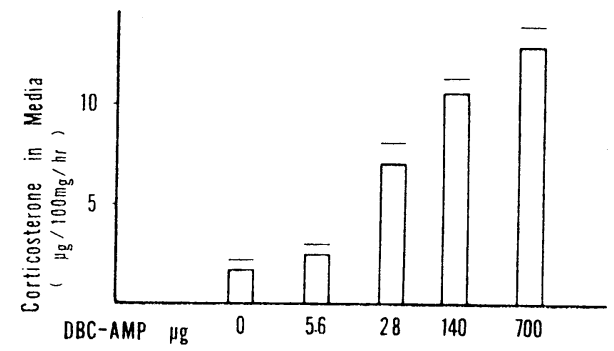

Fig. 3. Effect of alprenolol (a beta blocker) on adrenal steroidogenic response to ACTH in vitro. Each bar represents the mean \pm SEM.
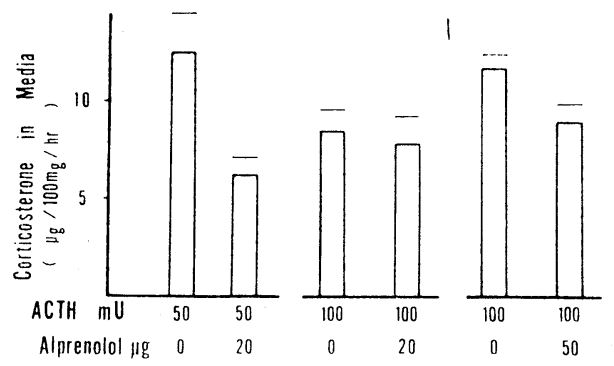

Fig. 5. Effect of thymoxamine (an alpha blocker) on adrenal steroidogenic response to ACTH in vitro. Each bar represents the mean \pm SEM.

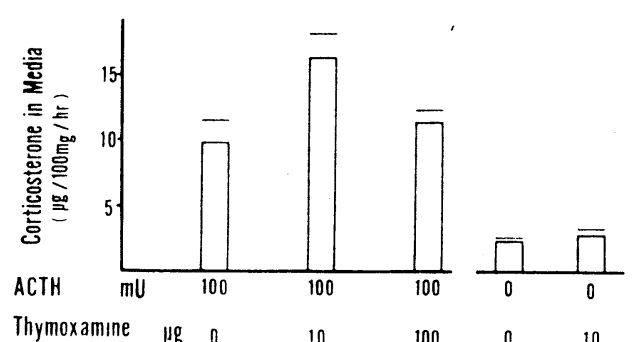

Fig. 2. Effect of propranolol (a beta blocker) on adrenal steroidogenic response to ACTH in vitro. Each bar represents the mean \pm SEM.

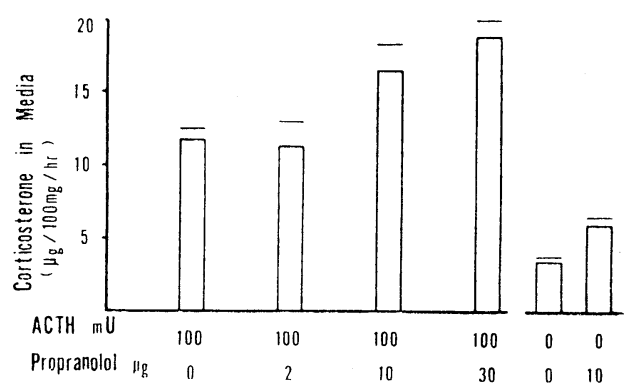

Fig. 4. Effect of isoproterenol (a beta stimulant) on adrenal steroidogenic response to ACTH in vitro. Each bar represents the mean $\pm \mathrm{SEM}$.

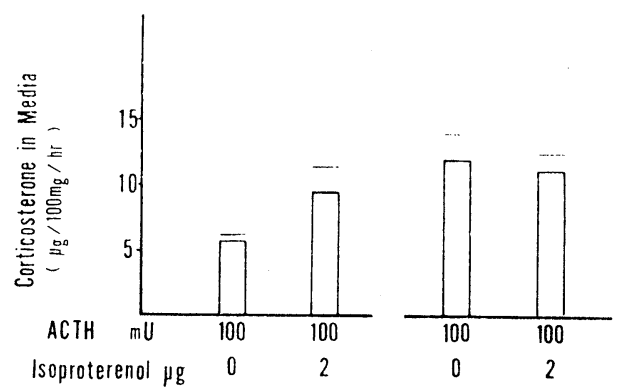

Fig. 6. Effect of methoxamine (an alpha stimulant) on adrenal steroidogenic response to ACTH in vitro. Each bar represents the mean \pm SEM.

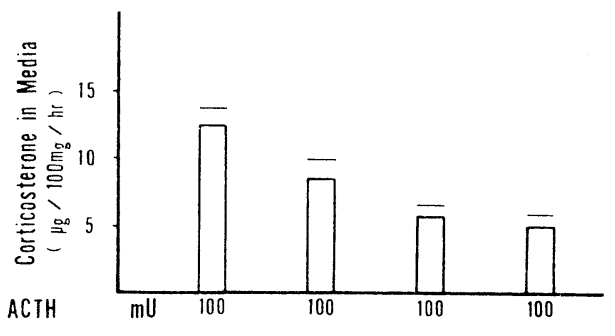

Methoxamine $\quad \mu \mathrm{g} \quad 0 \quad 2 \quad 10 \quad 40$

われわれは $\beta$-blocker, propranolol がin vivoでACTHのステロイド産生作用を増強するととを認めた ${ }^{12)}$ が， in vitroでも dose-dependentなステロイド産生増強作用がみられた (Fig. 2) しかし $\beta$-blocker, alprenolol はむしろ ACTH のステロイド産生を抑制した (Fig. 3)。 $\beta$-stimulator, isoproterenol は ACTH の 作用に影響しないかむしろ增強した (Fig. 4)。 $\alpha$-blocker, thymoxamine は $10 \mu \mathrm{g} / 2 \mathrm{ml}$ の濃度で ACTH 
Table 1. Effect of adrenergic agents on adrenal steroidogenic response to ACTH in vitro. $\uparrow, \downarrow$, and $\rightarrow$, represent potentiation, inhibition, and no effect, respectively.

\section{ALPHA STIMULANT \\ METHOXAMINE $\downarrow$ PHENYLEPHRINE $\rightarrow$ \\ ALPHA BLOCKER \\ THYMOXAMINE $\uparrow$ PHENTOLAMINE $\rightarrow$ \\ BETA STIMULANT \\ ISOPROTERENOL $\rightarrow$ \\ BETA BLOCKER \\ ALPRENOLOL}

のステロイド産生を促進したが(Fig. 5)， $\alpha$-blocker, phentolamine は用いた濃度では効果がなかつた。 $\alpha$-stimulator, methoxamine は ACTH のステロ イド産生を著明に抑制したが (Fig. 6)， $\alpha$-stimulator, phenylephrine は用いた濃度では一定の効果を梕めなかつた。. 以上各 adrenergic agent の ACTHに よるステロイド産生への影響を一括表示すると Table 1 の如くで, $\beta$-blocker, propranolol を例外として ACTH の作用は $\alpha$-receptor を介して抑制的に， $\beta$-receptor を介して促進的に働いている事か明らかであ る.

そとでさらに鬼副腎皮質を用いて同様に検討すると白ネズミ副腎でみられたように propranolol は $\mathrm{ACTH}$ のステロイド産生を増強したが, cycloheximide $0.8 \mathrm{mg} / 2 \mathrm{ml}$ の添加でも propranolol によるとみな されるステロイド産生は全く抑制されなかつた (Fig.7)。 また EGTA を加えた Ga++ free の medium 中でも propranolol によるとみなされるステロイド産生は抑制がみられず, 本剤がステロイド産生過程の どの部位に作用するかを決定するてとは極めて困難であつた． そとで corticosterone の螢光測定に際して 通常 medium に加える $10 \mu \mathrm{g} の$ propranolol を water blank, corticosterone $1 \mu \mathrm{g}$ に添加すると明らか な硫酸螢光への干渉を認めた (Fig. 8). 螢光測定に用いる励起光 $464 \mathrm{~m} \mu$ で corticosterone, propranolol の螢光スペクトルを描くと $526,515 \mathrm{~m} \mu$ にそれぞれ peak を有する極めて類似した pattern を程した. 従 つて propranolol の ACTH によるステロイド産

Table 2. Effect of adrenergic agents on adenyl cyclase activity in adrenal in vitro. Values are the mean of duplicate determinations.

\begin{tabular}{|c|c|}
\hline & $\begin{array}{r}{ }^{14} \text { C.Cyclic AMP Produced } \\
(\mathrm{cpm})\end{array}$ \\
\hline Propranolol $5 \mathrm{Hg}$ & 13,366 \\
\hline Alprenolol 10 & 14,784 \\
\hline Isoproterenol 2 衹 & 17,185 \\
\hline Thymoxamine $5 \mathrm{Hg}$ & 15,182 \\
\hline Phentolamine 5 将 & 14,883 \\
\hline Control & 14,395 \\
\hline
\end{tabular}

Fig. 9. Effect of adrenergic agents on phosphodiesterase activity in adrenal in vitro. Values are the mean of duplicate determinations.

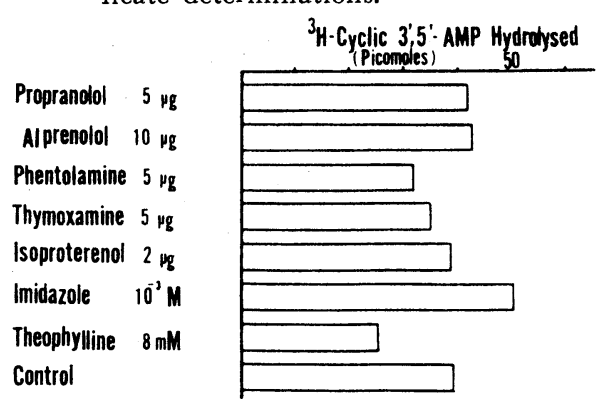


Fig. 10. Effect of prostaglandin $E_{1}$ on adrenal steroidogenesis in vitro. Each bar represents the mean \pm SEM.

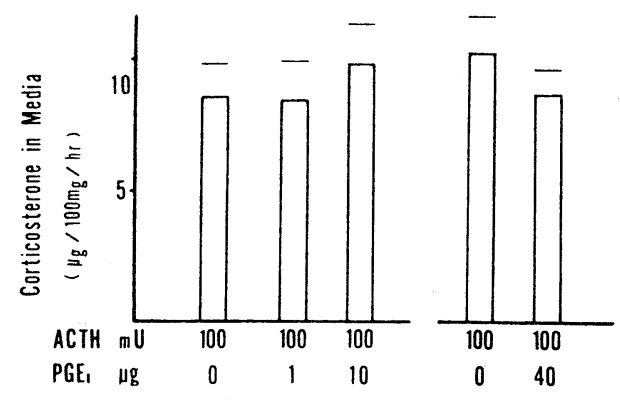

Fig. 12. Effect of theophylline on adrenal steroidogenesis in vitro. Each bar represents the mean \pm SEM.

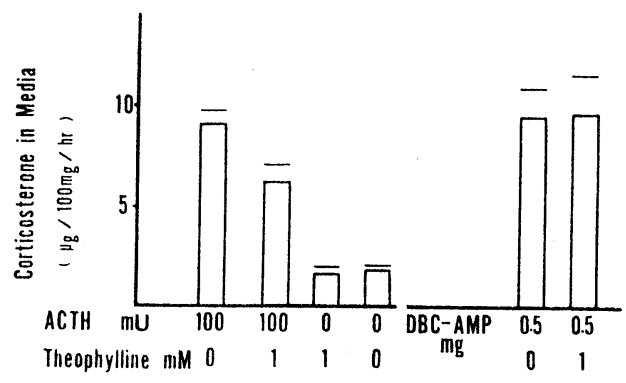

Fig. 14. Effect of cycloheximide on adrenal steroidogenesis in vitro. Each bar represents the mean $\pm S E M$.

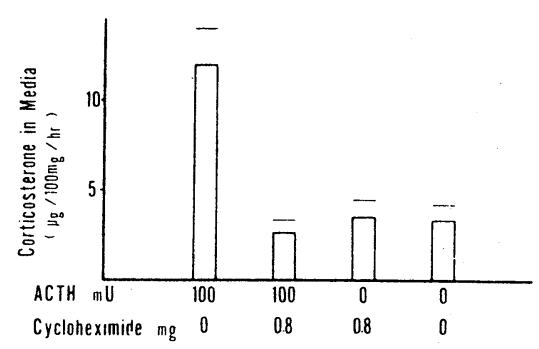

Fig. 11. Effect of calcium removal and EGTA on adrenal steroidogenesis in vitro. EGTA was added to give a final concentration of $1 \mathrm{mM}$. Each bar represents the mean \pm SEM.

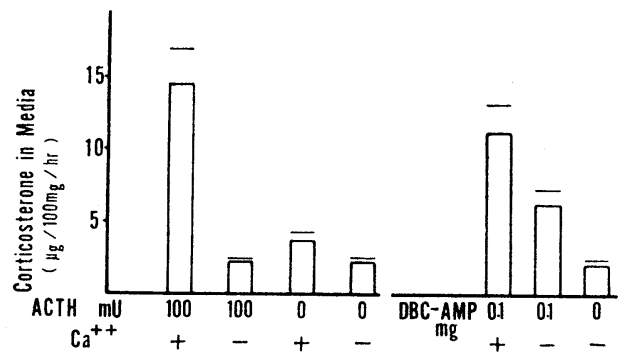

Fig. 13. Effect of imidazole on adrenal steroidogenesis in vitro. Each bar reIpresents the mean \pm SEM.

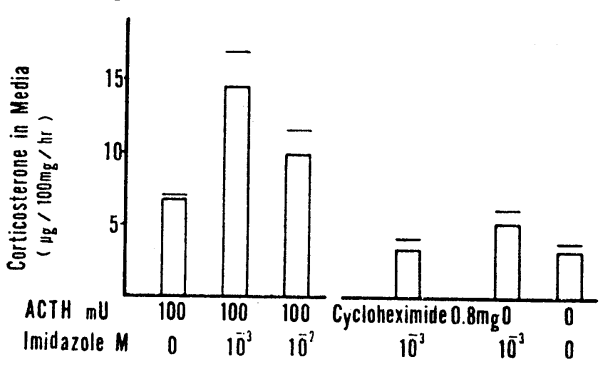

生への影響は螢光測定への干造によるみかけの促進 作用であることが明らかとなつた。

次に adrenergic agents $の$ 副腎 adenyl cyclase 活 性への影響を ${ }^{14} \mathrm{G}-\mathrm{ATP}$ の ${ }^{14} \mathrm{C}-\mathrm{C}-\mathrm{AMP}$ への転換で みると propranolol で抑制, isoproterenol, thymoxamine で促進を認め (Table 2), in vitro でのス テロイド産生におよぼす効果 と一致する結果 を得 た.また各種 adrenergic agent の副腎 phosphodiesterase 活性への効果を ${ }^{3} \mathrm{H}-\mathrm{C}-\mathrm{AMP}$ の水解の度 合により比較すると, adrenergic agents では対照 と有意の差を認めなかつた（Fig.9).

以上の結果より adrenergic agents は adenyl cyclase 活性への効果を介してステロィド産生へ影響しているものと考えられる.

3) prostaglandin $\mathrm{E}_{1}$ の in vitro でのステロイド産生への影響 用いた各濃度とも ACTH のステロ イド産生に一定の効果を認めなかつた（Fig. 10).

4) $\mathrm{Ca}^{++}$の in vitro でのステロイド産生への影響 second incubation の medium $\mathrm{Ca}^{++}$を加え ず EGTA を $1 \mathrm{mM}$ の濃度に加えると AGTH のステロイド産生は全く抑制され，AGTH を加えない basal level も低下した. 一方 DBC-AMP のステロイド産生も一部抑制された (Fig. 11). 
5 ) theophylline および imidozole の in vitro でのステロイド産生への影響 G-AMP を水解する phosphodiesterase の抑制剤および促進剤である theophylline と imidazole のステロイド産生への影響 をみると，前者は ACTH の作用をむしろ抑制し DBG-AMP によるステロイド産生にも効果がなかつた (Fig. 12). 一方後者は ACTH の作用を抑制するどてろか促進効果がみられた (Fig. 13). AGTH を加え ない basal level での imidazole のステロイド産生促進作用は蛋白合成阻止剂 cycloheximide の添加に より抑制された (Fig. 13)。また phosphodiestraseへのてれら薬阂の影響をみると, imidazole は酵素活性 を促進し, theophylline は逆に抑制することが認められた（Fig. 9).

6) cycloheximide の in vitro でのステロイド産生への影響 蛋白合成阻止剂 cycloheximide の添加 により ACTH によるステロイド産生は全く抑制された. なお ACTH を加えない basal level の抑制は みられなかつた (Fig. 14).

\section{4 考按}

Sutherland ら ${ }^{22)}$ は ACTH を含む各 hormone が target organ に作用する際に先ず細胞膜 adenyl cyclase を活性化し ATP よりの C-AMP の産生を促がし，ての C-AMP が細胞内で second messenger として酵素の活性化，ホルモンの産生，紐胞膜透過性の変化などの組織特有な現象を惹起するという two messenger system 説を提唱している. また細胞膜 adenyl cyclase は各 hormone が撰択的に作用する膜 外面の regulatory unit と，その情報により細胞内で ATP より G-AMP を産生する膜内面の catalytic unit よりなるとされている7). しかも hormone の adenyl cyclase への作用は $\alpha$-receptor を介して抑制 的に， $\beta$-receptor を介して促進的に働らくことが adrenergic agents を用いた実験により catecholamines 2)7), vasopressin' ${ }^{2)}, \mathrm{MSH}^{13)}$ で明らかにされている.

副腎皮質での adrenergic receptor に関しては Cushman ら ${ }^{14)}$ が大副腎の灌流実験で adrenergic blocking

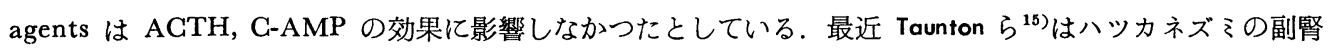
腫演を゙用い propranolol が ACTH による adenyl cyclase の活性化を完全に抑制するてとを報告してい る. われわれは今回， $\beta$-blocker, propranolol のステロイド産生促進作用は corticosterone の螢光測定への 干渉による見かけのものであり，ACTH の副㹂皮質での作用にも他の hormone でみられる adrenergic receptor の原則があてはまるととを in vitro のステロイド産生わよび adenyl cyclase 活性の測定により 明らかにした。同系統の adrenergic agent でもその効果が一致しなかつたのは添加した用量および各

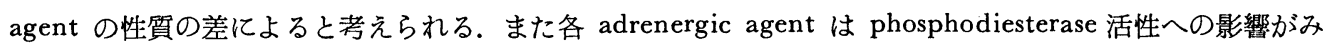
られなかつたととより主に adenyl cyclase に作用するてとが明らかである.

prostaglandin $\mathrm{E}_{1}$ の副腎皮質への影響についてはまだ一致した見解をみないが(15)16)，今回の実験では ACTH のステロイド産生作用に対して一定の効果を認めなかつた。

ACTH の副腎皮質での作用に $\mathrm{Ca}^{++}$が必要であるととは, in vitro のステロイド産生 ${ }^{17)}$, 副腎 adedyl cyclase 活性化 ${ }^{18)}$ への影響で確かめられている. 本実験でも $\mathrm{Ca}^{++}$を添加せず $1 \mathrm{mM}$ の濃度に EGTA を 加えた medium では AGTH のステロイド産生が完全に抑制された. 一方 DBC-AMP の作用も一部抑制 されたととにより $\mathrm{Ca}^{++}$は DBG-AMP の細胞内への透過性あるいは G-AMP 産生以後のステロイド産生 経路にも作用している可能性が推測される.

一般に methyl xanthines は C-AMP の水解酵素 phosphodiesterase 活性を抑制し ${ }^{2) 3)}$, その結果 GAMP が細胞内に蓄積するため theophylline の添加により ACTH, G-AMP によるステロイド産生作用は 増強することが予想されるが，今回の実験でも theophylline はむしろ抑制ないし効果のないてとが観察さ れた. Halkerston ら ${ }^{19}$ は theophylline によりステロイド産生に必要な蛋白合成が阻害されるのがその原因 であろうとしている. 一方 imidazole は phosphodiesterase 活性をたかめ ${ }^{22)}$ C-AMP の破壊を促進するた め AGTH のステロイド産生を抑制すると考えられるが，本実験ではむろ増強するてとを認めた。 cycloheximide の添加により ACTH を加えない basal level での imidazole によるステロイド産生が抑制され 
たととより，恐らく本㶡は蛋白合成系に促進的に作 用するのではないかと推測される.

AGTH によるステロイド産生が各種蛋白合成阻 止剂により完全に抑制されること放 22), cycloheximide 添加により AGTH によるステロイド産生 が抑制された場合にも G-AMP の増加は認められ るとどょり，AGTH により G-AMP が産生され， 次いでこの C-AMP により turn over の早やい regulatory protein がつくられ，との蛋白が未だ不 明の機序により mitochondria 内での cholesterol から pregnenolone への醉素的水酸化反応による転換を促進しステロイド産生が起てると考えられている 23). 今回の実験でも cycloheximide の添加により in vitro での AGTH によるステロイド産生の完全な 抑制を認めた。

5 結 語

以上の ACTH による副腎皮質ステロイド産生経路とてれに関与する諸因子の作用部位を一括すると Fig. 15 の如くである. われわれは今回特に adrenergic agents の副腎での AGTH の作用にわける意義を 明らかにし, さらに prostaglandin $\mathrm{E}_{1}$, theophylline, imidazole, $\mathrm{Ca}^{++}$, cycloheximide などの効果につ いても検討し若干の興味ある事実を認めた。

謝辞 本シンポジゥムに参加の機会を与えられた西川光夫会長, 座長の山村雄一, 宇井信生の諸教授に 深謝いたします。また共同研究者京都大学第二内科井村裕夫，加藤讓の両先生に感謝いたします。

\section{文献}

1) HAYNES. R.C., JR., E.W. SUTHERLAND and T.W. RALL : Recent Prog. Horm. Res., 16 : 121, (1960)

2) ROBISON, G.A., R.W. BUTCHER and E.W. SUTHERLAND : Ann. Rev. Biochem., 37 : 149, (1968)

: Circulation, $37: 279$, (1968)

3) SUTHERLAND, E.W., G.A. ROBISON and R.W. BUTCHER

4) IMURA, H., S. MATSUKURA, H. MATSUYAMA, T. SETSUDA and T. MIYAKE : Endocrinology, $76: 933$, (1965)

5) GRAHAME-SMITH, D.G., R.W. BUTCHER, R.L. NEY and E.W. SUTHERLAND : J. Biol. Chem., 242 : 5535, (1967). 6) HILF, R. : New Eng. J. Med., 273 : 798, (1965). 7) ROBISON, G.A., R.W. BUTCHER and E.W. SUTHERLAND : Ann. New York Acad. Sc., 139 : 703, (1967). 8）井村裕夫 : 内科宝函, $9: 130,(1962)$.

9) TAUNTON, O.D., J. ROTH and I. PASTAN : Biochem. Biophys. Res. Comm., $29: 1$, (1967). 10) KUO, J.F. and E.C. DE RENZO : J. Biol. Chem., $244: 2252$, (1969). 11) CHASE, L.R., S.A. FEDAK and G.D. AURBACH : Endocrinology, $84: 761$, (1969). 12）井村裕夫, 松山 均, 松倉 茂: 日本臨牀, $27: 103$, (1969). ABE, K., G.A. ROBISON, G.W. LIDDLE, R.W. BUTCHER, W.E. NICHOLSON and C.E. BAIRD : Endocrinology, 85 : 674, (1969). 14) GUSHMAN, P., S. ALTER and J.G. HILTON : J. Endocr., $34: 271$, (1966).

15) TAUNTON, D.P., J. ROTH and I. PASTAN : J. Biol. Chem., $244: 247$, (1969).

16) FLACK, J.D., R. JESSUP and P.W. RAMWELL : Science, $163: 691$, (1969).

17) BIRMINGHAM, M.K., F.H. ELLIOTT and H.-L., VALERE : Endocrinology, $53: 687,(1953)$. 18) BÄR, H.-P. and O. HEGHTER : Biochem. Biophys. Res. Comm., 35 : 681, (1969). 
Exp. Biol. Med., 122 : 896, (1966).

20) FERGUSON, J.J. JR. : J. Biol. Chem., $238: 2754$, (1963). 21) GARREN, L.D., R.L. NEY and W.W. DAVIS : Proc. Nat. Acad. Sci., 53 : 1443, (1965). 22) FARESE, R.V. : Biochim. Biophys. Acta, 87 : 699, (1964).

23) GARREN, L.D. : Vitamines and Hormones, 26 : 119, (1968). 